\title{
Contrition, Confession, and the Power of the Keys in the Summa Halensis
}

\begin{abstract}
This study addresses the sacrament of penance as it is treated within the Summa Halensis, specifically focusing upon the role that contrition plays in relation to confession. In order to provide proper context for this treatment in the Summa Halensis, we will examine a range of discussions throughout the $12^{\text {th }}$ and early $13^{\text {th }}$ centuries, in addition to the section on penance in Alexander of Hales' Gloss of Lombard's Sentences. We would be confident in saying that the Summa Halensis, like the earlier Gloss, held that contrition on the part of the penitent is the determining factor in the forgiveness of sins apart from subsequent acts of confession and satisfaction. One central question, however, is precisely how the Summa Halensis explains contrition's relationship to the duties of confession and satisfaction, which still remained vital components of the sacrament. A simple answer to this question is not forthcoming; there may even be a shift of position not only from the Gloss to the Summa Halensis, but even within the Summa Halensis itself.
\end{abstract}

Is heartfelt sorrow coupled with frank acknowledgement to God of one's sin and a sincere vow to sin no more enough to secure divine forgiveness, or must one make a formal confession to a priest before one can attain pardon? In the most simplistic terms, is it in contrition or confession that the sinner finds justification? In his classic study of the sacrament of penance in the $12^{\text {th }}$ century, Paul Anciaux observed that in the wake of Peter Abelard, and despite the reaction of the Victorines, the consensus among the masters was that sins are forgiven in the contrition of the penitent. Strictly speaking, therefore, confession was not indispensable for the remission of sins. Given the efficacy assigned to contrition, rooted in the fundamental principle that God alone forgives sins, there was no choice but to render sacerdotal power of a secondary order. ${ }^{1}$ Two decades earlier Amédée Teetaert similarly concluded that among the first scholastic theologians, confession was seen to have been established in order for penitents to manifest their contrition rather than submitting their sins to the absolution of a priest. Hence the power of the keys was not extended to the remission of guilt and eternal punishment; absolution was merely an official declaration of the pardon already granted by God. These theologians, therefore, attributed the principal role in justification to the subjective acts of the penitent. ${ }^{2}$ Both Anciaux

1 Paul Anciaux, La Théologie du Sacrament de Pénitence au XII Siècle (Louvain: Nauwelaerts, 1949), esp. 608-14 for a summary.

2 Amédée Teetaert, La Confession aux Laïques dans L'Église Latine Depuis le VIII au XIV Siècle: Étude de Théologie Positive (Paris: Gabalda, 1926), 256.

D OpenAccess. (c) 2020 Lydia Schumacher, published by De Gruyter. (c))BY-NC-ND This work is licensed under the Creative Commons Attribution-NonCommercial-NoDerivatives 4.0 License. 
and Teetaert had, of course, surveyed a range of opinions during this period which were often quite nuanced. And more recently, Joseph Goering has argued that there were not yet two opposing schools of thought in the $12^{\text {th }}$ century, one which favored interior contrition and the other external confession. What took place in the classrooms, according to Goering, was more conversation than debate as a range of views was canvassed. Although he finds that Peter Lombard along with Gratian of Bologna largely established the framework of the discussion going forward. ${ }^{3}$

This study will address the sacrament of penance as it is treated within the Summa Halensis $(\mathrm{SH})$, specifically focusing upon the role that contrition plays in relation to confession. In order to provide proper context for this treatment in the $S H$, we will need to examine a range of discussions throughout the $12^{\text {th }}$ and early $13^{\text {th }}$ centuries, in addition to the section on penance in Alexander of Hales' Gloss of Lombard's Sentences. We would be safe in saying at the outset, however, that the $\mathrm{SH}$, like the earlier Gloss, held that contrition on the part of the penitent is the determining factor in the forgiveness of sins apart from subsequent acts of confession and satisfaction. A central question that emerges, though, is precisely how the $S H$ explains contrition's relationship to the aforementioned duties of confession and satisfaction, which still remained vital components of the sacrament. As we will see, a simple answer to this question is not forthcoming; indeed, there may even be a shift of position not only from the Gloss to the $\mathrm{SH}$, but even within the $\mathrm{SH}$ itself.

\section{The Legacy of the $12^{\text {th }}$ Century}

Thoughtful theological analysis of the sacrament of penance begins in the first half of the $12^{\text {th }}$ century with the writings of Hugh of St Victor and Peter Abelard. In his 1130 De sacramentis christianae fidei, Hugh made one of the strongest cases for the vital role that the priesthood plays in the sacrament of penance. He was making his case in dialogue with those who (he says) ascribe the power to forgive sins to God alone, and concede no measure of human participation. Much like the priests of the Old Law who only confirm that the leper has already been cleansed, so it is now that someone who is first absolved by the Lord through contrition of heart is later shown to have been absolved by priests through confession of mouth. Sins, therefore, have previously been forgiven through contrition. Those who make this argument, however, do not claim that confession of the mouth is therefore unnecessary. Neglecting to confess, having obtained pardon for one's sins, would be to show contempt for a divine institution. Even while one is no longer liable for sins already forgiven, consequently, one still remains liable for the contempt. Nevertheless the point is made that

3 Joseph Goering, 'The Scholastic Turn (1100-1500): Penitential Theology and the Law in the Schools,' in A New History of Penance, ed. Abigail Fiery (Leiden: Brill, 2008), 219 - 37. See also Joseph Goering, 'The Internal Forum and the Literature of Penance and Confession,' Traditio 59 (2004): 175227. 
human beings have no power to forgive sins; that power belongs to God alone. Hugh then proceeds to offer a careful analysis of the process of repentance. He makes it clear first of all that just as no one after the fall could rise from sin unless divine mercy would first gratuitously rouse one, so God in his mercy quickens us to repentance through no merit of our own and thereby restores the grace that had been lost. Grace therefore stirs our hearts to repent, such that we are absolved from the debt of damnation. Where does the priest fit into all of this? Hugh draws upon the popular example of Christ raising Lazarus from the dead (John 11:43-44). Christ first absolved Lazarus internally from the bond of spiritual death and then ordered that he be released from his external bonds through the ministry of the apostles. So now in the Church, Christ by grace vivifies the dead internally and arouses them from their sins such that they feel remorse. He then sends them to confess where, through the ministry of the priests, he absolves them from the exterior bond of damnation. Hugh insists, however, that he is not thereby attributing to priests the power to forgive sins. Christ as God can indeed forgive sins apart from human cooperation; yet he can also do through a human being what he does by himself. This is not to say that human beings therefore do nothing even as God works through them. Hugh notes that the power of the keys was not granted to Peter alone, for Christ says to all the apostles and to the successors of the apostles who function in their place: 'Receive the Holy Spirit, whosever sins you forgive will be forgiven them ( ... )' (John 20:22-23). It is no wonder, therefore, that human beings can forgive sins, since they have received a share of Christ's divine power. For God to grant this power to human beings is nothing else than for God to do this work through humans. In that sense, according to Hugh, the Church's priests do have the power of binding and loosing as granted to them by God. For even though God can forgive sin directly, it is fitting that human beings be made co-workers in the salvation of sinners. The sinner's redemption begins with contrition, to be sure, but it is fully perfected when one confesses by mouth what one already grieves over in one's heart. ${ }^{4}$

We turn now to Peter Abelard who had stated in his circa 1139 Scito te ipsum that three things are necessary for the reconciliation of sinners to God: penitence, confession, and satisfaction. ${ }^{5}$ Penitence itself is defined as sorrow of mind for having strayed from the right path. ${ }^{6}$ After surveying what constitutes unfruitful penitence which is rooted in fear of punishment and self-interest, Abelard defines a fruitful penitence as sorrow and contrition of mind that is born of love for God. ${ }^{7}$ What he says next proved to be of great import for discussions in succeeding generations: sin cannot co-exist with contrition of heart, which Abelard designates as true peni-

\footnotetext{
4 Hugh of St Victor, De sacramentis Christianae fidei 2.14.8, ed. Rainer Berndt (Münster: Aschendorff, 2008), 529-36; PL 176:564-570.

5 Peter Abelard, Scito te ipsum 1.51, in Petri Abaelardi Opera Theologica, vol. 4, ed. Rainer M. Ilgner, Corpus Christianorum Continuatio Mediaevalis, 190 (Turnhout: Brepols, 2001), 51.

6 Peter Abelard, Scito te ipsum 1.52 (Ilgner, 51).

7 Peter Abelard, Scito te ipsum 1.58 (Ilgner, 58).
} 
tence. For the love of God that inspires such contrition is incompatible with guilt. In fact, it is in this state of contrition that we are immediately reconciled to God and obtain pardon for our previous sins. At that instant the sinner is found worthy of forgiveness on account of divinely inspired contrition and is released from the debt of eternal punishment. Hence were someone to die, despite being prevented from first making one's confession and act of satisfaction, one could still be confident in salvation. ${ }^{8}$ Although it should be said that while this person has been pardoned of his eternal offense, he or she may still have further acts of atonement to perform. Those who die prior to performing all the requisite acts of satisfaction would therefore complete their penance in purgatory. ${ }^{9}$

Given that Abelard had counted confession among the three central components of reconciliation, we are left to ask why someone would seek confession having already been pardoned through their contrition. The first reason, he says, is that we might be helped by the prayers of those to whom we confess; the second, because confession of one's sins to another requires humility and thus is an action of atonement; and finally, because priests have been entrusted with the care of souls and therefore can prescribe suitable acts of penance. In that sense they function as doctors who must examine the wound they would then try to heal. ${ }^{10}$ Having said that, Abelard frankly grants that there are cases in which one could avoid, or at least delay, confession without incurring sin if one believed that it would do more harm than good. So long as this is not done out of contempt for God, says Abelard, the person would incur no guilt. ${ }^{11}$ Admittedly, such occasions would be the exception, and so Abelard counsels people generally to seek those to whom our souls have been committed and follow their advice even if we reckon the priest to be otherwise lacking in good qualities. ${ }^{12}$

In his opening comments of the Tractatus de penitentia, written circa 1142 and thus a decade before Peter Lombard's Sententiae, Gratian of Bologna laid out the fundamental question circulating in the $12^{\text {th }}$-century schools which we alluded to above: whether by contrition of the heart alone, and secret satisfaction, apart from confession of the mouth, anyone would be able to satisfy God. According to Gratian, there are some who say that pardon for sin can be merited apart from ecclesiastical confession and sacerdotal judgment. ${ }^{13}$ Two schools of thought are then presented here: one saying that contrition as a rule leads to remission of sin, and another that mere contrition is salvific only under exceptional circumstances. Atria Larson, in her 2014 study of Gratian, has argued that no one at this time actually negated

8 Peter Abelard, Scito te ipsum 1.59 (Ilgner, 55-9).

9 Peter Abelard, Scito te ipsum 1.59 (Ilgner, 59).

10 Peter Abelard, Scito te ipsum 1.65 (Ilgner, 65-6).

11 Peter Abelard, Scito te ipsum 1.68 (Ilgner, 68).

12 Peter Abelard, Scito te ipsum 1.70 (Ilgner, 70).

13 Gratian of Bologna, Tractatus de penitentia, d. 1, prol., in Corpus iurus canonici, 2 vols, ed. Emil Friedberg (Leipzig: Tauchnitz, 1879; repr. Graz: Akademische Druck- u. Verlagsanstalt, 1959), 1:1159. 
the obligation to confess to a priest. Instead, the question was primarily concerned with the precise moment that $\sin$ is remitted during the penitential process. ${ }^{14} \mathrm{Al}$ though in 2016 John Wei has argued that Gratian set himself to address what he reckoned a genuinely open question at the time: whether, in fact, penitents were bound to confess their sins to a priest. ${ }^{15}$

As Gratian summarized the first position, we see that as far as its proponents were concerned, sins are clearly forgiven by contrition of the heart, not by oral confession; the disposition of the penitent's heart is the key element. ${ }^{16}$ We are resuscitated through grace and thus become sons of light prior to our confession. For nobody will confess unless spiritually alive, living and loving in Christ, and thus in a state undeserving of hell. Because such a state is incompatible with sin, God must already have removed this person's sin prior to his confession. Remission of sin will therefore come by way of contrition as God vivifies the soul prior to, and even apart from, confession. ${ }^{17}$

Here we are left to ask what confession by mouth accomplishes if sins are remitted already in contrition? It would seem that it serves to demonstrate one's repentance, even as it does not confer pardon. It may therefore be likened to the circumcision given to Abraham as a sign, but not a cause, of his justification (CF. Rom. 4:II). Likewise, then, confession to a priest presents a sign of pardon received, but is not the cause of that pardon. If this is the first position, the second finds that even as contrition remains necessary, no one can be cleansed from sin apart from confession and satisfaction, so long as there is time to accomplish these two things. Only in this most extreme of cases, such as intervening death, would contrition alone be sufficient for the remission of sins. ${ }^{18}$ Having explained both positions, Gratian explicitly leaves it to the judgment of the reader which to follow, since both positions, he says, have wise and religious supporters. ${ }^{19}$ Jean Gaudemet has opined that this surprising display of reserve on Gratian's part, having devoted so much time to laying out the different positions over the course of 89 canons, proves that the debate over confes-

\footnotetext{
14 Atria A. Larson, Master of Penance: Gratian and the Development of Penitential Thought and Law in the Twelfth Century (Washington, DC: The Catholic University of America, 2014), 35-40. See also Larson's new edition: Gratian's Tractatus de penitentia: A New Latin Edition with English Translation, ed. and trans. Atria A. Larson, Studies in Medieval and Early Modern Canon Law, 14 (Washington, DC: The Catholic University of America, 2016).

15 John C. Wei, Gratian the Theologian, Studies in Medieval and Early Modern Canon Law, 13 (Washington, DC: The Catholic University of America, 2016), esp. 103-6.

16 Gratian of Bologna, Tractatus de penitentia, d. 1, d.p.c. 30 (Friedberg, 1:1165).

17 Gratian of Bologna, Tractatus de penitentia, d. 1, d.p.cc. 36 and 37 (1) (Friedberg, 1:1167); Larson, Master of Penance, 42-55; Wei, Gratian the Theologian, 106-10.

18 Gratian of Bologna, Tractatus de penitentia, d. 1, d.p.c. 37 (2) (Friedberg, 1:1167); Larson, Master of Penance, 63-4; Wei, Gratian the Theologian, 111-2.

19 Gratian of Bologna, Tractatus de penitentia, d. 1, d.p.c. 89 (Friedberg, 1:1189).
} 
sion was not closed in the middle of the $12^{\text {th }}$ century. The canonists were still uncertain as to the respective importance of contrition, confession, and satisfaction. ${ }^{20}$

In his circa 1155 Sententiae Peter Lombard had noted that with respect to the performance of penance there are three central components: compunction of heart, confession of mouth, and satisfaction in deed. ${ }^{21}$ The question arises soon enough, though, as to whether sin can be remitted by contrition of heart alone apart from the aforementioned satisfaction and confession of mouth. ${ }^{22}$ Now it would seem that just as inward penance is enjoined upon us, so also is confession by mouth and outward satisfaction if there is opportunity to accomplish these tasks. Offering what proves to be a crucial distinction here, the Lombard will insist that someone cannot be considered truly penitent if lacking the intention to confess. With that in mind, though, it remains the case that remission of sins is granted prior to confession, but tempered with the proviso that one intends to confess when given the opportunity to do so. ${ }^{23}$ Having granted that sins are entirely remitted by God through contrition of heart, and from the moment that the penitent has the intention of confessing, what exactly is the priest cleansing if God has already acted on the basis of the penitent's contrition? Having surveyed many opinions on this point, the Lombard alights upon what he reckons the most appealing: God alone, not the priest, remits the debt of eternal death, just as he vivifies the soul interiorly. The Lombard repeats this principle in one form or another as he then states that Christ's grace enlightens the soul inwardly and simultaneously releases the soul from the debt of eternal death. Then, having cited Augustine, Cassiodorus, and Jerome, he concludes that God absolves the penitent from the debt of punishment when he inwardly illuminates that person inspiring true contrition of heart. One is not freed from eternal wrath upon confession to a priest, therefore, since the contrite person has already been set free by the Lord. One has thus ceased to be a child of wrath from the moment one has begun to love and repent. ${ }^{24}$ Amidst the many and varied opinions advanced by the doctors, the Lombard determines that God remits sins by himself alone in such a way that he both cleanses the soul from inward stain and liberates it from the debt of eternal death. ${ }^{25}$

Finally, we should note that it was the Lombard who laid out the three tiers within penance considered precisely as a sacrament. There is the sacrament alone (sac-

20 Jean Gaudemet, 'Le débat sur la confession dans la Distinction I du "de penitentia" (Decret de Gratien, C. 33, q. 3),' Zeitschrift der Savigny-Stiftung für Rechtsgesichte 71 (1985): 52-75.

21 Peter Lombard, Sententiae in IV libris distinctae 4, d. 16, c. 1, 1, 2 vols, ed. Ignatius Brady, Spicilegium Bonaventurianum, 4-5 (Grottaferrata: Editiones Collegii S. Bonaventuare, 1971-81), 2:336.

22 Peter Lombard, Sententiae 4, d. 17, c. 1, 1 (Brady, 2:342).

23 Peter Lombard, Sententiae 4, d. 17, c. 1, 13 (Brady, 2:346).

24 Peter Lombard, Sententiae 4, d. 18, c. 4, 1-6 (Brady, 2:357-8). See also Marcia L. Colish, Peter Lombard, 2 vols, Brill's studies in intellectual history, 41 (Leiden: Brill, 1994), 2:583-609, who argues that the Lombard was staunchly committed to the 'contritionist' perspective and did not shrink from all that entailed.

25 Peter Lombard, Sententiae 4, d. 18, c. 5, 5 (Brady, 2:360). 
ramentum tantum) which is exterior penance; the sacrament and reality (sacramentum et res) which is inward penance; and the reality alone (res tantum) which constitutes the remission of sins. Interior penance is the reality (res) of the outward penitential action, although it also functions as the sacrament (sacramentum) of the remission of sin, which it both signifies and brings about. ${ }^{26}$

If Peter Lombard followed Abelard in emphasizing contrition as the decisive factor in the remission on sins, Richard of St Victor assigned to the priest a much more substantial role in this process. In his De potestate ligandi et solvendi, Richard did indeed admit that confession of heart suffices for the salvation of one's soul, since at the point of death, confession to a priest and absolution can be excluded. In that sense, it is true that the Lord alone absolves. Yet, says Richard, confession to a priest is still required, inasmuch as this faculty has been divinely bestowed by God working through his minister. ${ }^{27}$ What Richard goes on to say will prove of significant import for Alexander's Gloss and also for the $S H$ itself. For here Richard maintains that when the Lord looses the bonds of damnation, he does so conditionally (conditionaliter); the priest for his part does so unqualifiedly (simpliciter) or fully (integraliter). So it is, according to Richard, that God absolves the penitent from the debt of damnation under the condition that, if one is able, one will seek the absolution of a priest and make the requisite satisfaction. Were the penitent to neglect to fulfill this obligation, he or she would not manage to escape eternal danger. Yet having received the absolution of a priest, and having thus fulfilled the terms of the condition, were that person to die immediately afterwards, he or she would no longer face the threat of eternal damnation. Sinners absolved by the priest still remain obligated to fulfill their assigned penance if they hope to avoid the fire of future purgation. In that sense, even as the priest releases the penitent from the debt of eternal damnation fully and unqualifiedly, he releases that person from the debt of future purgation only conditionally (sub conditione); it is conditional upon making satisfaction. ${ }^{28}$

An important development in penitential practice occurred in 1215 when the Fourth Lateran Council mandated that all men and women confess their sins at least once a year to their own priest (proprio sacerdoti) and strive to fulfill the penance enjoined upon them. This constitution, Omnis utriusque, began to circulate soon after the council's conclusion and then entered into 1234 Decretales Gregorii IX. ${ }^{29}$ In 1216, within a year of the council, Thomas de Chobham produced his Summa confessorum, which would become a hugely popular manual for priests. At the outset of his

26 Peter Lombard, Sententiae 4, d. 22, c. 2, 5 (Brady, 2:389-90).

27 Richard of St Victor, Tractatus de potestate ligandi et solvendi 7 (PL 196:1164D-1165A).

28 Richard of St Victor, Tractatus de potestate ligandi et solvendi 8 (PL 196:1165B-1165D). Note that Teetaert, La Confession aux Laïques, 257 credits Richard with inaugurating the theory of conditional forgiveness.

29 See Lateran IV, constitution 21, in Enchiridion Symbolorum: definitionum et declarationum de rebus fidei et morum, ed. Heinrich Denzinger and Adolf Schönmetzer (Rome: Herder, 1976), n. 812. Cf. Decretalium D. Gregorii Papae IX. 5.38.12, in Corpus iurus canonici (see above, n. 13), 2:887. 
practical guide Thomas addressed the nature of the sacrament itself and its three components: contrition, confession, and satisfaction. Taking as a given here that all guilt is remitted by contrition alone, Thomas must explain to these priests why one would bother go to confession. To that end Thomas evokes the example of the sick person who, although he has gotten considerably better, still faces some ailments which will need to be cured. So it is that, following the remission of guilt, there remain further complications which will have to be cleansed through confession and satisfaction, such as the pleasurable memory of sin and the difficulty of refraining from one's old ways. Confession and satisfaction, with the sense of shame that they induce, will prove helpful in this regard. What is more, though, the merciful God who forgives sins is also the just God who demands satisfaction. It is from his great mercy, therefore, that God commutes eternal punishment into temporal. Thomas offers the example of mercy shown to a thief who deserves hanging; he is spared the death penalty by performing some alternative work of satisfaction. ${ }^{30}$

Having established that a genuinely contrite penitent has been forgiven his or her guilt even before approaching the priest, it would seem that there is nothing for the priest to absolve. Some people, according to Thomas, say that the priest absolves from sin inasmuch as he shows one to have already been absolved. This cannot be right, however, since the priest never reveals who has come to confession. Better to say, therefore, that the priest has freed the penitent from the obligation of the penitential forum as well as the accusations of the devil. ${ }^{31}$ Like a judge absolving an innocent defendant from the claims of a fraudulent plaintiff and thereby releasing him from future litigation, the priest does not actually absolve the penitent of any sin, since that has already been dismissed through his contrition; he does absolve him from any obligation to confess this sin again or face future accusations leveled by the devil for this $\sin ^{32}$

Finally, with Omnis utriusque clearly in mind, Thomas maintains that when a Christian sins he or she should immediately repent in their heart and resolve to go to confession during Lent. It would actually be better to run to a priest immediately after sinning; but if one repents in one's heart, waiting until Lent is alright. ${ }^{33}$ Having repented in one's heart and resting secure in his forgiveness, one should look forward to making one's confession, just as the sick person who is sure his or her illness is not getting worse can more easily anticipate further medical treatment. ${ }^{34}$

Within the schools at this time, the Parisian master and canon of Meaux, Guy of Orchelles, produced a Treatise on the Sacraments around 1220 which synthesized the

30 Thomas de Chobham, Summa confessorum 1.2a, ed. F. Broomfield, Analecta mediaevalia Namurcensia, 25 (Louvain: Éditions Nauwelaerts, 1968), 8-9.

31 Thomas de Chobham, Summa confessorum 5.1.8a (Broomfield, 207).

32 Thomas de Chobham, Summa confessorum 5.1.8a (Broomfield, 207-8).

33 Thomas de Chobham, Summa confessorum 5.2.2a (Broomfield, 236).

34 Thomas de Chobham, Summa confessorum 5.2.2a (Broomfield, 236-7). See Lateran IV, constitution 22, in Enchiridion Symbolorum, n. 815. 
work of previous Parisian scholars, notably Praepositinus of Cremona and Stephen Langton, on the subject of penance, transmitting these ideas to scholars at Paris in the 1230 s and 1240 s. $^{35}$ Here contrition is presented as an action of the soul punishing itself and thereby acquiring merit, and so commuting eternal into temporal penalty. ${ }^{36}$ In keeping with what had become the standard line, though, to spurn the sacrament of confession would result in the forfeiture of the fruit of one's contrition, namely, remission of sins. ${ }^{37}$

Addressing the precise relationship between grace and contrition, Guy finds that divine power, i.e. grace expels sin prior to the infusion of created grace. Hence created grace does not itself co-exist with sin in the same subject. Rather, says Guy, outer grace (gratia extra) has already rid the soul of sin prior to the arrival of inward grace (gratia infra). The terminology and process outlined here anticipates the later process of grace freely given (gratia gratis data) followed up by sanctifying grace (gratia gratum faciens). ${ }^{38}$ As for the role of the priest in all of this, he functions as a herald of celestial judgment, announcing the divine decision. The priest reveals whether sins have been forgiven or retained by God, thereby completing in some way the divine sentence while enjoining a temporal penalty in place of eternal punishment. Then, by authority of the keys, the priest may release one from that temporal penalty. ${ }^{39}$

Guy's contemporary William of Auxerre explored a three-fold forum: that of God, the Church, and the penitent. There may be a person so contrite that he or she has been absolved by God, yet has not completed the penance imposed by the Church, or perhaps has done so but is not sure the act of satisfaction was sufficient. Or again, someone might manifest contrition great enough to erase not only his or her sin, but achieves such a sense of inner security and spiritual joy as to feel released from the debt of punishment. Absolved in both in the divine and personal forum, therefore, this person still remains subject to the act of penance that the Church imposes. ${ }^{40}$

William was clearly interested in the subjective side of the sacrament, the conscience of the penitent and the penitent's capacity for spiritual growth, which can be furthered in the act of confessing one's sins. Not only can the priest help the penitent to recognize his or her sin but its gravity, but the sense of shame aroused in the revealing of one's sins can result in a spiritual purgation. The very act of going to

35 Guy of Orchelles, Tractatus de sacramentis ex eius Summa de sacramentis et officiis ecclesiae, ed. Damian and Odulf Van den Eynde, Franciscan Institute Publications Text Series, 4 (St Bonaventure, NY: Franciscan Institute Publications, 1953), esp. 102-66. My thanks to Riccardo Saccenti for alerting me to this text.

36 Guy of Orchelles, Tractatus de sacramentis 6.2.106-7 (Van den Eynde, 107-8).

37 Guy of Orchelles, Tractatus de sacramentis 6.2.112 (Van den Eynde, 111-2).

38 Guy of Orchelles, Tractatus de sacramentis 6.2.113 (Van den Eynde, 113-4).

39 Guy of Orchelles, Tractatus de sacramentis 6.4.136 (Van den Eynde, 139-40).

40 William of Auxerre, Summa Aurea 4.8.2, 7 vols, ed. Jean Ribaillier, Spicilegium Bonaventurianum, 16-20 (Paris: Editions du Centre National de la Recherche Scientifique (CNRS); Grottaferrata: Editiones Collegii S. Bonaventurae, 1980-7), 6:199-200. 
confession, even if one's devotion may be lukewarm, can yield tremendous benefits. According to William, a person who comes to confession in a state of spiritual aridity may leave fully hydrated. For it is often within the priest-penitent encounter that the person, by the very act of confessing, will erase his or her sins and receive the infusion of grace. Even someone already possessing grace may find that confessing results in the further increase of grace. ${ }^{41}$

Before turning our attention to Alexander of Hales and the $S H$, it is worth briefly revisiting the canon law. As touched upon above, the canonists were intensely interested in the sacrament of penance in light of its myriad pastoral implications. Theologians, whose own work both informed the canon law and was informed by it, had to stay abreast of the most recent formulations and applications of that law. Not surprisingly, therefore, the Glossa Ordinaria on Gratian's Decretum provides a concise status quaestionis on penance in the first decades of the $13^{\text {th }}$ century. The Gloss begins by noting that contrition of the heart is itself a sign that sins have been forgiven, just as exterior satisfaction serves as a sign of contrition. Grace, therefore, precedes contrition; and remission of sin is thus attributed to grace. Yet, as the Gloss notes, others say that sins are forgiven through contrition with respect to guilt, but not with respect to punishment. Still others maintain that remission of sins is rendered conditional through contrition of the heart. And some say that because we offend God in three ways, namely, heart, mouth, and deeds, so three modes of satisfaction are required. Hence all three are necessary: contrition of heart, confession of mouth, and works of satisfaction. As for those authorities who say that sins are remitted by contrition alone, the Gloss reckons this to apply in cases of extreme necessity which makes confession of mouth impossible, e.g. when the contrite person is prevented by death from making his or her confession or faces some other serious obstacle. Peter Manducator is named among those who believe that remission of sins becomes conditional through contrition of heart. Huguccio for his part says that by contrition of heart alone sins are forgiven in any adult. Although we again find this caveat: if someone is contrite, proposes to abstain from further sin, plans to confess, and to submit to the judgment of the Church, that one will be forgiven, although actual confession and satisfaction fail to follow. This person sins mortally, however, if in keeping with the Church's precept, he or she is able to confess and perform the work of satisfaction and yet fails to do so..$^{42}$

41 William of Auxerre, Summa Aurea 4.10.1 (Ribaillier, 6:243-4).

42 Gratian of Bologna, Tractatus de penitentia, d. 1, prol. (Friedberg, 1:1159); Corpus juris canonici emendatum et notis illustratum: Gregorii XIII. pont. max. iussu editum, 3 vols (Rome: In aedibus Populi Romani, 1582), 1:2185-6. 


\section{Review of Scholarship on Alexander of Hales and Penance}

In a substantial article from 1969, Thomas Jarosz surveyed the scholarship regarding Alexander's position on penance. Here he recounted M. dos Reis Miranda's 1951 study of Alexander wherein Miranda had argued that Alexander should not be placed among the so-called contritionists. ${ }^{43}$ Instead, he believed, the essence of sacramental penance for Alexander rested in the words of absolution offered by the priest, which is to say that an attrite penitent attains genuine contrition by means of sacramental absolution. Jarosz concluded, however, that Miranda had completely misread Alexander in his attempt to bring the Alexander of the Gloss into line with Tridentine theology. In fact, says Jarosz, Alexander's teaching was very much in keeping with the scholastic tradition that followed upon Peter Lombard. Jarosz sees in Alexander not an innovator, but a traditionalist. For Jarosz the authentic Alexander is to be found in the Gloss, and there Alexander is a contritionist. Jarosz was therefore critical of those scholars who attempted to construct Alexander's teaching on the basis of the $\mathrm{SH}$, some of whom, such as A. Michel, had published their findings prior to the discovery and publication of the Gloss. ${ }^{44}$ A corrective, according to Jarosz, was offered by A. Vanneste, ${ }^{45}$ who concluded that Alexander fell into line with Hugh of St Cher and Philip the Chancellor in the tradition of Peter Lombard. On his view, guilt and eternal punishment are removed through the personal contrition of the penitent, whereas confession, absolution, and satisfaction pertain to the deletion of temporal punishment. Jarosz for his part wished to return to the Gloss for its insights into the authentic teaching of Alexander on penance apart from the expansion and innovation he believes to be found in the later $S H$, indebted to William of Melitona, Odo Rigaldus, and Bonaventure. ${ }^{46}$

It should be noted, however, that already in 1925, and thus before the critical edition of the Gloss, Amédée Teetaert had argued first of all that the $\mathrm{SH}$ does in fact reflect the authentic teaching of Alexander even though it was composed by other friars; it was a work initiated under Alexander's direction and faithfully transmits his ideas. With regard to the sacrament of penance as treated in the $S H$, Teetaert de-

43 M. dos Reis Miranda, 'A doutrina da Penitência nas obras inédita de Alexandre de Hales,' Colectanea de Estudos 2 (1951): 205- 406.

44 A. Michel, 'Pénitence du IV concile du Latran à la Réforme,' in Dictionnaire de théologie catholique, vol. 12/1, ed. Jean Michel Alfred Vacant, Eugène Mangenot, and Émile Amann (Paris: Letouzey et Ané, 1933), 956-7.

45 Alfred Vanneste, 'La théologie de la pénitence chez quelques Maîtres Parisiens de la première moitié du XIIIe siècle,' Ephemerides Theologicae Lovanienses 28 (1952): 24-58.

46 Thomas Jude Jarosz, 'Sacramental Penance in Alexander of Hales' Glossa,' Franciscan Studies 29 (1969): 302-346. See too Kilian F. Lynch, 'The Doctrine of Alexander of Hales on the Nature of Sacramental Grace,' Franciscan Studies 19 (1959): 334-83. Lynch, in his analysis of the Gloss, likewise places the emphasis for Alexander squarely on contrition as the means to forgiveness of sins. 
termined that it is indeed contrition which plays the chief role and constitutes the principal factor in the justification of the sinner. Priestly absolution, therefore, exercises no real efficacy with respect to the remission of guilt, although the keys do alleviate temporal punishment in keeping with the power that Christ gave to the apostles. $^{47}$

\section{Alexander's Gloss on the Sentences}

According to Alexander's Gloss on the Lombard's Sentences (1223-27), there are two effects resulting from penance: remission of guilt and remission of penalty. It is through contrition that guilt is remitted, whereas by confession and satisfaction, the penalty is alleviated, although the penalty can sometimes be lifted by means of contrition alone. With respect to the remission of guilt, penance may be counted as a grace, since the effect of erasing guilt is proper to grace. With regard to the remission of punishment, however, penance is a virtue, since the person in the state of charity makes satisfaction and renders to God what he or she owes, and this belongs to justice. Penance may therefore be considered a work that proceeds from charity and justice. ${ }^{48}$

The Gloss finds that term penance (poenitentia) can be taken in many ways. It can apply to attrition or repentance, such that the one who repents, even if not in a state of sanctifying grace (gratia gratum faciente), is nevertheless rendered capable of achieving this state with the assistance of grace freely given (per gratiam gratis datam). Hence the process begins with the grace freely given (gratia gratis data) and continues all the way through to the infusion of sanctifying grace (gratia gratum faciens), which occurs simultaneously with the remission of sins. On other occasions, however, 'penance' is taken for contrition or the effect of repentance; and then again for the will of contrition; the virtue enabling the will; the sacrament of penance; the act of confessing; or the enjoined penalty. So it is that 'penance' may be defined as a voluntary affliction for sin, for the sake of God, directed towards the remission of guilt and penalty. Insofar as it is a sacrament, penance functions both as a sign and a cause of grace. It is a sign without being a cause when it is received from the priest, which presupposes the preceding contrition in which grace is infused. It is important to note therefore that the assumption of the enjoined penance signifies, but does not itself cause, the grace by which guilt is remitted in contrition. It may at times be a cause of grace alone without being a sign, however, provided the spiritual sorrow felt in one's heart does not produce an exterior sign such as

47 Amédée Teetaert, 'Doctrine d'Alexandre d'Alés au sujet du sacrament de Pénitence,' Études franciscaines 37 (1925): 337-54. See also Teetaert, La Confession aux Laïques, 262-5.

48 Alexander of Hales, Magistri Alexandri de Hales Glossa in quatuor libros Sententiarum Petri Lombardi (hereafter, Glossa) 4, d. 14, 6, 4 vols, Bibliotheca Franciscana Scholastica Medii Aevi, 12-5 (Quaracchi: Collegium S. Bonaventurae, 1951-7), 4:210-1. 
tears. At the same time, however, it must be said that penance cannot be designated as a cause of grace if the penitent is not disposed to take on an enjoined penance. Finally, penance functions as both cause and sign when that interior spiritual sorrow does burst forth into an exterior corporeal sign, thereby signifying the grace of the remission of eternal punishment. ${ }^{49}$

The question then arises as to whether the three components of penance (contrition, confession, and satisfaction) are all integral to the sacrament. That they are not seems clear enough, since contrition on its own sometimes suffices for the deletion of both guilt and penalty. Here the Gloss draws a vital distinction when it observes that contrition can actually be said to constitute the esse of penance inasmuch as it is the cause of the deletion of sin, whereas confession and satisfaction belong merely to the bene esse. In that sense one could say that penance, considered precisely as a sacrament, can be completed in contrition. Or it may be considered as an act of satisfaction rendered to the Church, in which case it cannot be accomplished apart from taking on the penance enjoined by the priest from the power of the keys in confession. ${ }^{50}$

From this twofold perspective of personal and corporate responsibility, the Gloss will assert that the deletion of guilt may take place with respect to God through contrition or with respect to the Church through confession within the penitential forum. ${ }^{51}$ Hence while it remains true that contrition alone can delete in God's sight both the guilt and penalty associated with sin, this does not hold in the forum of the Church. Furthermore, the unity of charity by which the mystical body is united assists the penitent in the remission of sin through the supplications of the priest beseeching God's forgiveness. Thus even as sin could be remitted through contrition, it is not done easily apart the sacerdotal supplications offered within the unity of the Church. ${ }^{52}$ The Church thereby proves helpful to the penitent as she aids one in the quest for salvation, which means that her assistance should be sought.

An important question then emerges as to whether the Lord not only blots out the stain of sin, but also the liability of eternal punishment; or whether the priest dismisses this liability by the power of the keys. Now some will contend that the Lord immediately dismisses the liability, since it is owed to the guilt which he has himself forgiven. Moreover, eternal punishment, precisely because it is eternal, is in the power of God alone; hence it is only for God to dismiss. On the other hand, Richard of St Victor (not Hugh as the Gloss has it) points out that although God by himself releases the penitent from bonds of obduration, God works through his minister to release him from the debt of eternal damnation. For even as the Lord remits guilt in contrition, he obliges the penitent to his due satisfaction following confes-

49 Alexander of Hales, Glossa 4, d. 14, 6, 4:211; on the working of grace see also Glossa 4, d. 17, 5, 4:278.

50 Alexander of Hales, Glossa 4, d. 16, 1, 4:252-3.

51 Alexander of Hales, Glossa 4, d. 16, 7, 4:257.

52 Alexander of Hales, Glossa 4, d. 17, 15, 4:296. 
sion. And so, if one does not confess, one remains a debtor to eternal punishment. It is this debt that is absolved when one takes up his penance in confession. Since this is what the priest accomplishes by the power of the keys, it is the priest who dismisses the liability to eternal punishment. Hence when someone makes a worthy confession, we say that the priest releases him from the bonds of eternal damnation. Here Richard's De potestate ligandi et solvendi is quoted directly: 'The Lord releases conditionally (conditionaliter), whereas the priest does so fully (integre). ${ }^{53}$

Having presented the case, the Gloss offers a conclusion that sticks very close to Richard. For it affirms that when the Lord forgives guilt in contrition, he releases one unqualifiedly (absolute) from the bonds of captivity and servitude to sin and the devil. But this same person is released from the bonds of eternal damnation only conditionally (conditionaliter), since one must still confess if one has the opportunity-although if that is impossible then he is absolutely released. Note that God, in releasing someone from the bonds of eternal damnation, nevertheless obliges this person to the bonds of expiation through purgatorial punishment. It is from this latter bondage that a priest can release someone through the temporal punishment that he enjoins upon him subsequent to confession. And so it is clear, according to the Gloss, that even as remission of one's liability to eternal punishment comes from God, the penitent is absolved of purgatorial punishment by taking on the penance enjoined by the priest through the power of the keys. In that sense one may say that the sentence is forgiven by God through the ministry of the priest. This is why some have maintained that the Lord by means of his priests forgives the sentence of eternal punishment, rather than saying that this offense is unqualifiedly (simpliciter) dismissed by the Lord. ${ }^{54}$ Finally, on this point, the Gloss notes that although in contrition, the liability to eternal punishment is dismissed by grace conjoined to spiritual sorrow, the bonds of confession still remain. Were one not released, therefore the penitent could find himself once again in the bonds of eternal damnation; hence the need for taking on the bonds of expiation. This question of the absolute and conditional release from the bonds of eternal punishment will later arise in the $S H$. For now, though, it may be fair to conclude that the Gloss, which had otherwise stuck close to Peter Lombard's 'contritionist' position, then veered into a Victorine 'confessionist' stance.

53 Alexander of Hales, Glossa 4, d. 18, 4, 4:320.

54 Alexander of Hales, Glossa 4, d. 18, 4, 4:322-3. 


\section{The Summa Halensis}

\section{Question 17: Contrition}

In Question 17 of Book 4 of the $S H$, we find contrition defined as an assumed sorrow for sins with the resolution to confess and make satisfaction. Thus one notes from the outset that, in keeping with Peter Lombard's position, genuine contrition contains within itself the intention on the part of the penitent to make an oral confession and to perform the prescribed works of satisfaction enjoined by the priest. The $S H$ thereupon continues by pointing out that contrition owes its inception to God who first grants grace to the soul. Having received this grace, one is then capable of assuming the sorrow for sin, which is contrition. Contrition is the indispensable first step which precedes confession, and they both precede satisfaction. The $S H$ further insists that the contrite person, unless he confesses and renders satisfaction if possible, remains a transgressor of the Lord's precept, and so will be condemned for the sin of this transgression..$^{55}$

One of the effects of contrition, according to the $S H$, is the justification of the impious. Justice itself is defined, in keeping with St Anselm, as rectitude of the will. In the process of justification, the soul is repaired and informed with justice and thus conformed to God. As a result of this deiformity, the soul is made pleasing or acceptable in God's sight. One's cognitive faculty is illuminated, affection set ablaze, and the operative faculty rectified. Thus it would seem for the $S H$ that contrition amounts to much more than the mere recognition of sin; it belongs to a whole process of human restoration. ${ }^{56}$ The justification of the adult, moreover, necessarily requires contrition. While it is true therefore that God does work virtue within us apart from our own efforts, this does not happen without sorrow for sins on our part. ${ }^{57}$

Perhaps, though, contrition is not in itself sufficient for absolving one of guilt. After all, it seems that a person could be at once contrite and guilty, which means contrition does not actually have the power to expel guilt. Gregory the Great had noted that someone weeping for his or her sins, who nevertheless does not desert the cause of that sin, is contrite in heart even as he or she refuses to be humbled. It stands to reason, therefore, that even though contrition is required for justification, it is not necessarily sufficient for justification; one could, in other words, be terribly sorry for one's sins and yet remain unjustified. According to the $\mathrm{SH}$, we must therefore distinguish here between contrition generally and properly speaking. Commonly it refers to all sorrow for sin, but properly only that sorrow for sin that is informed

55 Alexander of Hales, Alexandri Alensis Angli Summae Theologiae: Pars Quarta (hereafter, SH Bk IV), Q17, M2, Ar3 (Cologne: Sumptibus Ioannis Gymnici, sub Monocerote, 1622), 509-10. Note that I checked the Cologne edition against the Venice 1575 edition.

56 SH Bk IV, Q17, M4, Ar1, p. 534.

57 SH Bk IV, Q17, M4, Ar2, pp. 534-5. 
and caused by sanctifying grace (gratia gratum faciens). Hence if one is indeed to be purged of guilt through contrition, this will be because his or her sorrow was informed by divine grace. And this sort of genuine contrition, which affects the forgiveness of sins, includes the willingness to repent of one's sins. ${ }^{58}$

The $S H$ provides an analysis of the process by means of which the sinner finds forgiveness. The first stage involves freely given grace (gratia gratis data) through which the sinner is moved towards God. Here one comes to recognize the mercy of God, his forgiveness and munificence, and so is built back up again by hope. It is in this way that the sinner prepares himself for the reception of grace. One who was until this point unformed now becomes acceptable to God through grace. While it is true that the infusion of grace and the state of contrition are simultaneous in time, it must be said that grace is still prior in nature. In other words, one cannot be contrite without first having been informed by the sanctifying grace which enables true contrition. This description of the process is not, however, without its problems. If the infusion of grace precedes contrition, it would seem that a person could be just apart from contrition. That is to say, one could be in a state of grace and thus acceptable to God, without having demonstrated genuine sorrow for one's sins. The $\mathrm{SH}$ meets this objection, however, noting that this would only hold if the infusion of grace were prior to contrition not only in nature, but also in time. Yet, as we have seen, the infusion and the contrition are simultaneous; there is no 'moment' in which the person is just without being also contrite. ${ }^{59}$

In keeping with what we have sketched above, the $S H$ observes that in the process of justification there is required on the part of God the infusion of sanctifying grace (gratia gratum faciens), while on our part the sorrow of contrition is required. If this is the case, then in preparation for this event, there is first required from God the grace freely given (gratia gratis data), while we exhibit the sorrow of attrition. So it is that in the consummation of justification, which comprises absolution from guilt and punishment, three sorts of sorrow are required at different stages: before justification, coexisting with the process of justification, and subsequent to justification. The first is the sorrow of attrition; the second, sorrow of sacramental contrition; and the third, sorrow of satisfactory contrition. Contrition for its part proceeds in a certain sense from a movement of the free will, because it stems from the instinct of a formed faith; whereas attrition, which also stems from the movement of a free will, arises from the prompting of an unformed faith. This is the customary way that the process works, according to the $S H$, although there are special cases, such as St Paul's Damascus Road experience, when God justifies someone at once without preparation. ${ }^{60}$ It should also be pointed out that contrition and attrition, although both gifts from God

58 SH Bk IV, Q17, M4, Ar3, p. 535.

59 SH Bk IV, Q17, M4, Ar7, pp. 548-51.

60 SH Bk IV, Q17, M5, Ar2, p. 553. 
and the result of grace, cannot exist simultaneously any more than could an unformed and formed faith. ${ }^{61}$

Note that two Franciscans who were involved in the final compilation of the $S H$, William of Melitona and Odo Rigaldus, adopt similar positions in their own work. In his Quaestiones de sacramentis, William had likewise determined that it is grace freely given (gratia gratis data) which elicits the movement of free will to experience sorrow for one's sins, thereby setting the stage for the subsequent gratuitous infusion of sanctifying grace (gratia gratum faciente). Then, with the advent of sanctifying grace, the penitent's attrition becomes contrition. It is thus through freely given grace that someone recognizes the wounds of sin, an awareness which is followed by the sanctifying grace that leads one to seek a doctor. ${ }^{62}$ As such, therefore, confession and satisfaction do not precede the illumination of faith or grace; rather it is the intention to confess and perform satisfaction that often precedes illumination. ${ }^{63}$ As for Odo, in his concise De contritione he observed not only that contrition and attrition are unqualifiedly different, but that attrition cannot become contrition. ${ }^{64}$ Attrition remains a partial sorrow for some sins which is moved by grace freely given, according to Odo, whereas contrition grieves fully for all sins and is itself informed by sanctifying grace. ${ }^{65}$ Attrition cannot, moreover, abide together with contrition, since the former is an act elicited from an unformed faith and thus cannot co-exist with the latter act elicited from a formed faith. And while both attrition and contrition are gifts of God, the former lacks charity whereas the latter signifies a movement of the will with charity. ${ }^{66}$ So it is that the presence of contrition, i.e. actual sorrow for sin is necessary for the justification of the sinner. ${ }^{67}$

Such attention paid to attrition was relatively recent, for as Anciaux points out 'attrition' does not really appear as a technical term in theological discussions of penance until the end of the $12^{\text {th }}$ century. Then, by the $13^{\text {th }}$ century, many concluded that attrition can become contrition through grace. ${ }^{68}$ On this point Teetaert finds that both Alexander and Bonaventure were heavily indebted to William of Auvergne who had already developed a clear distinction between attrition and contrition. In his De sacramentis, William maintained that attrition was sufficient to approach the sacra-

\footnotetext{
61 SH Bk IV, Q17, M5, Ar3, p. 553.

62 William of Melitona, Quaestiones de Sacramentis, tr. 5, p. 3, q. 12, ed. Caelestinus Piana and Gedeon Gal, 2 vols, Bibliotheca Franciscana scholastica Medii Aevi, 22-3 (Quaracchi: Collegium S. Bonaventurae, 1961), 2:870.

63 William of Melitona, Quaestiones de Sacramentis, tr. 5, p. 4, q. 25 (Piana and Gal, 2:927).

64 Odo Rigaldus's De contritione can be found in Toulouse, Bibliothèque Municipale 737, fols 221231. See Jeanne Barbet, 'Notes sur le manuscrit 737 de la Bibliothèque municipale de Toulouse: Questiones Disputatae,' Bulletin d'information de l'Institut de Recherche et d'Histoire des Textes 5 (1956): 7-51, esp. 42.

65 Odo Rigaldus, De contritione (Toulouse, Bibliothèque Municipale 737, fol. 222rb).

66 Odo Rigaldus, De contritione (Toulouse, Bibliothèque Municipale 737, fol. 222va).

67 Odo Rigaldus, De contritione (Toulouse, Bibliothèque Municipale 737, fol. 222vb).

68 Paul Anciaux, Le Sacrement de la Pénitence (Louvain: Nauwelaerts, 1960), 139-46.
} 
ment of penance, although he insisted that to obtain forgiveness of sins, attrition would have to change to contrition, which itself constitutes the principal part of penance. The priest's role in this transformation, however, is only to beseech God that he might bestow upon the penitent pardon and sanctifying grace. The priest's words of absolution do not render a judicial sentence, therefore, but amount to a prayer. Priestly absolution is merely an occasional, rather than an instrumental, cause of the forgiveness of sins. This view was shared by Alexander (on which more below) ${ }^{69}$

\section{Question 18: Confession}

From here the $S H$ takes up the subject of confession in Question 18, which is defined as a complete confession of one's own sins, not those of another, made in the presence of a priest; not, therefore, to God alone. ${ }^{70}$ We are then, naturally enough, brought back to the central question as to whether confession to a priest by the penitent is actually necessary. An appeal is made to Augustine, although the text quoted is from Gratian's Decretum: it is the will that is rewarded, not the deed; yet the will is in contrition of heart, while the work is in confession of the mouth. Hence it is by contrition of heart, not confession of mouth, that sins are remitted. ${ }^{71}$ And so it would seem that if sin is blotted out by contrition rather than confession, the latter must be unnecessary for the penitent. Moreover, while justification suffices for the salvation of the penitent, confession is not required for the justification of the impious. There are only four things required: the infusion of grace, the movement of the free will, contrition, and forgiveness of sins. Furthermore, contrition on the part of the penitent suffices for the deletion of guilt and punishment, while the deletion of guilt and punishment, for their part, suffice for salvation. Responding to these arguments, the $\mathrm{SH}$ insists that confession on the part of the penitent is necessary by reason of a precept whether instituted by Christ or by the Church. For it is necessary that we do those things which Christ and the Church have established, lest we be found to hold those precepts in contempt. Confession is also necessary inasmuch as it is only fitting that the sinner, having sinned against God and the Church, be reconciled to the Church which is itself the Body of Christ. Hence it may be said that whereas we are reconciled to God by way of contrition, it is by confession that we are reconciled to the Church. ${ }^{72}$

69 William of Auvergne, De sacramento poenitentiae, in Guilielmi Alverni Opera omnia, 2 vols (Venice: Apud Ioannem Baptistam Natolinum, sumptibus Damiani Zenari, 1591), esp. c. 4, 2:44 1b and c. 19, 2:472 g. See Teetaert's discussion, La Confession aux Laïques, 260 -2.

70 SH Bk IV, Q18, M1, pp. 556-7.

71 See Gratian of Bologna, Tractatus de penitentia, d. 1, d.p.c. 30 (Friedberg, 1:1165). Cf. similar sentiments expressed by Augustine, Enarratio in Psalmum 31 (PL 36:267-8).

72 SH Bk IV, Q18, M2, Ar1, p. 557. 
Confessing to a priest may indeed fulfill one's obligation, but what exactly takes place when priest and penitent meet? The $S H$ notes that while it is true that the diminution of the penalty occurs through the power of the keys, more importantly, God can reward the penitent with an increase of grace through a devout confession as God acknowledges the humility involved in confessing one's sins. Along these lines, the act of confessing one's sins to the priest might also lead to the remission of guilt. For it sometimes happens that someone who is not contrite prior to confession, subsequently, in the midst of confession, receives from God the grace of contrition; and so it is that the Lord justifies the person who freely confesses his sins. ${ }^{73}$ Note that it is God's direct action, not the sacerdotal power of the keys, which transforms the penitent's attrition into contrition, thereby resulting in his justification. William of Melitona, for his part, had also concluded the penitent need not be fully contrite upon meeting with the priest. Frequently, says William, the grace of contrition is actually given to one while one is making a sacramental confession, provided that the penitent places no obstacle to that grace. ${ }^{74}$ Neither, therefore, does William attribute this conferral of contrition to the sacerdotal power of the keys; it remains dependent upon the penitent's own disposition.

There certainly seem to be some positive incentives to make one's confession to a priest, since God may well reward one for this act of piety even to the point of moving one to the contrition that one hitherto lacked. But if it is true that sins are remitted with regard to guilt, is one actually obliged (rather than merely encouraged) to confess one's sin to a priest? According to the $\mathrm{SH}$, confession is indeed necessary. First of all, this is because there is no perfect or sufficient compunction unless the will to confess is present-a position explicitly attributed to Peter Lombard. And here in Question 18 the $S H$ then appears to endorse the position of Richard of St Victor that the Gloss had also followed. For, according to the $S H$, God does not remit sins in contrition unqualifiedly (simpliciter), but rather conditionally (sub conditione), that condition being that the penitent would confess his or her sins when the opportunity presents itself. In the meantime, between contrition and confession, sins are remitted-so long (it must be said) as the penitent retains the intention to confess. Lacking such an intention, his penitence or compunction will remain insufficient. ${ }^{75}$

The $S H$ insists again, this time with respect to the justification of the impious, that contrition is not sufficient without the intent to confess and the execution of that intention when the opportunity presents itself. Confession, therefore, implicitly belongs to the definition of contrition itself. Moreover, says the $\mathrm{SH}$, to the extent that there is contrition it is fitting that confession would follow unless the contrite person is somehow prevented; in that case, as with an adult wishing to be baptized, guilt can be removed through grace or the power of faith. Established teaching on baptism

73 SH Bk IV, Q18, M2, Ar1, p. 558.

74 William of Melitona, Quaestiones de Sacramentis, tr. 6, p. 3, q. 13 (Piana and Gal, 2:1046).

75 SH Bk IV, Q18, M2, Ar1, p. 558. 
actually provides a useful example: even as a willing adult may receive the baptism of the spirit, he or she should still seek out baptism by water in keeping with the Lord's admonition: 'Unless one be baptized by water and the spirit ( ... )' (John 3:5). Likewise, therefore, the intent to confess remains necessary, lest its omission be interpreted as contempt for the sacrament. ${ }^{76}$

Actually, according to the $S H$, the necessity of oral, or sacramental, confession is established under the evangelical law. First of all, one's sin must be brought into the open and followed by an act of reconciliation on the part of the sinner made to God and the Church. Confession, therefore, provides for the detection of sin and leads to one's subsequent conversion to righteousness when the works of darkness are rebuked. This occurs in confession as the truth is brought to light; the intelligible becomes sensible. By speaking hidden things, they are made manifest as one gives vocal form to words of the heart. The other purpose, as noted, is the free act of reconciliation made to God and the Church; it is in this context that the priest serves as judge and arbiter between the sinner and God. Christ the mediator has left to the Church his own successors whom the Church has instituted as revealers and arbiters, and to whom is committed the authority of reconciliation. Such authority that was first in Christ the head, and is now shared with his members, belongs uniquely to the time of the new law, although it had been already prefigured in the old law when priests had the authority to discern between the clean and unclean, holy and profane. ${ }^{77}$

\section{Question 19: Confession with respect to Absolution}

Where, precisely, in the Gospels was sacramental confession instituted? Some say it was when Jesus said, 'Go show yourself to the priests' (Matt. 8:4). Others note that neither the biblical text itself, nor the Glossa Ordinaria, actually mention vocal confession; in fact, the Glossa says just the opposite. ${ }^{78}$ Then there are those who say that it was instituted in Matt. 4:17 where the precept was given: 'Do penance' (poentitentiam agite). Yet to this it is objected that Gregory the Great takes this command as an injunction to produce suitable fruits of repentance, and thus satisfaction; while the Glossa says it refers to mortification of the flesh. ${ }^{79}$ And finally there is the problem that, unlike Baptism, which was expressly instituted by Christ, no such clear precept was given in this case. The $\mathrm{SH}$ is certain, however, that Christ did institute this sacrament, although one must recognize that there are two components in confession. The first is the material, which is the detection of sin; this was not openly instituted by Christ, but was instead insinuated. Then there is the formal, namely the power of ab-

76 SH Bk IV, Q18, M2, Ar1, p. 558.

77 SH Bk IV, Q18, M3, Ar1, p. 566.

78 Bibliorum Sacrorum cum Glossa Ordinaria, 6 vols (Venice: Apud Iuntas, 1603), 5:157-8.

79 Bibliorum Sacrorum cum Glossa Ordinaria, 5:69-70. 
solving, which was instituted in the conferral of the power of the keys. Formally, therefore, the Lord had instituted the sacrament by conferring the power of the keys upon Peter and the other apostles (Matt. 16:18 and John 20:23). ${ }^{80}$ Hence the sacrament that Christ instituted formally in the conferral of the keys was later promulgated by the Apostle James (James 5:16). ${ }^{81}$

What is at the root of the power to absolve sins? The $S H$ provides a comprehensive list of answers to this question: some say it is born of authority and thus belongs to God alone; others that it is an excellence pertaining to Christ the man; or a commission or ministry and thus for priests to whom was committed the power of absolving in the reception of priestly orders; or perhaps this power is grounded in a meritorious life and thus belongs to all the saints; and still others hold that it proceeds from the unity of faith such that it belongs to all the faithful. Now, according to the $S H$, these last two are really a matter of beseeching rather than efficacious or judicial power. For although it is sometimes expeditious to confess one's sins humbly to someone other than a priest, this is not a proper sacramental confession, even if it is a work of virtue. To priests alone, says the $S H$, has been handed down the reconciliation that comes through absolving and binding, which is why one is bound to confess to a priest. Thus when it comes to James' admonition-'Confess your sins to one another (...)' (James 5:16) - some, appealing to the Glossa Ordinaria, say that this applies only to venial sins which do not need to be confessed to a priest. $^{82}$ And yet since it was by those same words that sacramental confession seems to have been instituted or promulgated, one might say that confession can be taken in two ways: general and special confession. In both the general and the special there is confession to another person, but in special confession only to priests and in general to everyone. In that sense, then, James' single exhortation to confess can refer both to venial and to mortal sins, although with the proviso that to confess one's venial sins is only a counsel, whereas confession of mortal sins to a priest is a precept. $^{83}$

With the obligation to confess one's sins to a priest came a whole host of practical questions. Specifically, the $S H$ had to address the Lateran IV constitution Omnis utriusque that had been codified in the Gregorian Decretals. According to the $S H$, one should not take it upon oneself to confess to some other priest and thereby withdraw from one's own parish priest. Someone wishing to confess to another priest, therefore, should first obtain a license from his own priest; if one cannot obtain it, then one may receive it from a superior. One may even confess to his parish priest and then later seek out another more discrete priest of one's own choosing. ${ }^{84}$ As for women afraid to place themselves in danger by confessing to their own priest,

80 SH Bk IV, Q18, M3, Ar2, p. 567.

81 SH Bk IV, Q19, M1, Ar1, p. 596.

82 Bibliorum Sacrorum cum Glossa Ordinaria, 6:1303-4.

83 SH Bk IV, Q19, M1, Ar2, p. 596.

84 SH Bk IV, Q19, M1, Ar2, p. 596. 
they may confess to a superior or to some other priest without first obtaining a license. In this situation the corrupt priest would actually disqualify himself. For he would be dispensing the poison of death rather than the medicine of salvation, and so stand judged as a corruptor rather than a confessor. ${ }^{85}$

The Lateran IV constitutions had also insisted in the strongest terms that sacramental confession must not be revealed for any reason. The $S H$ recognizes that human existence is lived within both an interior and an exterior space. Within the interior forum of conscience, a person deals with those things that are to be kept secret, while the exterior forum pertains to the experiential wherein such things should be made manifest. What belongs to the interior forum of conscience must not be drawn into the exterior experiential forum, as would happen were a confession of sin revealed. What is confessed to a priest is secret, and it is only right that secret things remain hidden, since this pertains to faithfulness. There are clear pastoral concerns that must also be addressed: were a penitent's confession not to remain secret, it would be a thoroughly odious exercise that people would regard with horror. ${ }^{86}$

The question of finding a suitable confessor was also addressed in the Early Rule of 1221, the so-called Regula non bullata:

\begin{abstract}
Let all my blessed brothers, both clerics and lay, confess their sins to priests of our religion. If they cannot, let them confess to other discerning and Catholic priests, knowing with certainty that, when they have received penance and absolution from any Catholic priest, they are without doubt absolved from their sins, provided they have humbly and faithfully fulfilled the penance imposed on them. If they have not been able to find a priest, however, let them confess to their brother, as the Apostle James says: Confess your sins to one another (James 5:16). Nevertheless, because of this, let them not fail to have recourse to a priest because the power of binding and loosing is granted only to priests (cf. Matt. 18:18). Contrite and having confessed in this way, let them receive the body and blood of our Lord Jesus Christ with great humility $(. ..){ }^{87}$
\end{abstract}

It would seem, therefore, that the many contingencies surrounding the act of confession were still being worked out in the first few decades of the $13^{\text {th }}$ century and were of immediate concern to the Franciscans.

\title{
Question 20: The Keys of the Church
}

The power of absolution belongs to the larger context of the keys of the Church. Here, as touched on above, the principal texts are to be found in Matt. 16:18 and John 20:23. In keeping with the aforementioned schema, we read that the key of authority be-

85 SH Bk IV, Q19, M1, Ar2, p. 597.

86 SH Bk IV, Q. 19, M2, Ar1, p. 599.

87 'The Early Rule (The Rule Without a Papal Seal)' [=Regula non bullata], c. 20, in Francis of Assisi, Early Documents, vol. 1, The Saint, ed. Regis J. Armstrong, J.A. Wayne Hellmann, and William J. Short (Hyde Park, NY: New City Press, 2001), 77-8. 
longs to God alone; the key of excellence to Christ; while the key of ministry pertains to the prelates of the Church. To be clear: God alone has the authority to forgive sins, and only Christ can remove human liability to eternal death, since it was through his passion that he made satisfaction on our behalf and thereby liberated us from death. That leaves the last key pertaining to the removal of temporal punishment owed to sin; this is the key that Christ bestowed upon his priests. ${ }^{88}$

The key received by the priesthood must be considered both essentially and accidentally. Accidentally, it is a certain power of discernment which proceeds from knowledge, whether it be acquired or infused. Essentially, though, it is a sacramental power or authority conferred upon the priest in the reception of his orders. For in ordination a character is imprinted, inasmuch as the sacrament of order is a spiritual sign by which spiritual power is conferred upon the ordinand. To the objection that many priests appear to lack this power of discernment, the $S H$ finds that is not the case if one is considering knowledge precisely as a sacramental power or authority; such knowledge is a key and is conferred in the rite of ordination. This key, belonging to the priest, is a power both to remove an impediment and a means to discern the measure of guilt, by which is determined the measure of punishment. In this way, the power of knowledge can be seen to cooperate with the power to bind and loose. For Christ, having been constituted as a judge, has granted this authority to his ministers in the Church to distinguish between lepers (cf. Lev. 13:3-17), thus determining for the penitent the penalty appropriate to his guilt. Again, the $S H$ stresses, this key is granted in priestly ordination. In fact, if the priest ceased to possess such knowledge, i. e. the authority of discernment, he would cease to possess the key itself. ${ }^{89}$

As for the key that constitutes the power of binding and loosing, this was first given to Peter and afterwards to the other apostles, and then through them to their vicars. ${ }^{90}$ Matt. 16:18 would seem therefore to be a principal proof-text in establishing the conferral of the keys. Yet according to the $S H$ there are those who contend that the keys were not actually conferred upon Peter at Caesarea Philippi, but only promised. In fact, this is what Jerome says when commenting on the passage. What is more, it would seem that the one who received the keys could not err. Even though the words Tibi dabo claves are expressed in the mode of a promise regarding some future event, it is still the case that they were chiefly given to Peter along with the words 'Whatever you bind ( ... )', which the Glossa Ordinaria makes clear. ${ }^{91}$ What to make of all of this? According to the $S H$, a certain beatitude was granted to the Apostles such that they could not err in the exercise of the keys. To them grace was given to discern between different sorts of sin and so sins are not loosed unless they had been loosed and not bound unless they had been bound. This appears to have been a unique gift bestowed upon the Apostles alone, however,

88 SH Bk IV, Q20, M1, p. 603.

89 SH Bk IV, Q20, M3, Ar1, p. 605.

90 SH Bk IV, Q20, M3, Ar2, p. 605.

91 Bibliorum Sacrorum cum Glossa Ordinaria, 5:279-82. 
since there are many now who possess the keys while lacking the beatitude, which is to say that many clerics can indeed err in the exercise of the keys. ${ }^{92}$

The fact is that the power of the keys is given to good and bad ministers alike. It is a habitual key that follows upon ordination. And because it depends upon the dignity of priestly ordination itself, it is bestowed irrespective of the personal qualities of the ordinand. Thus even if the priest himself lacks charity he still retains the power of loosing in the faith and charity of the Church. This is because he does not possess the power of the keys though his own power, but only insofar as he is a minister of the Church. Were he to attempt to absolve by his own power, he could not do so unless he actually possessed faith and charity. Even if the ministers do not imitate the Apostles in manner of life, therefore, they nevertheless resemble them in ministerial order and power. ${ }^{93}$

\section{Question 21: The Power of the Keys}

Looking at Hugh of St Victor's reading of the Lazarus event (John 11:43-44), it would seem that Lazarus was first justified by Christ in his raising from the dead before he was handed over to the disciples to be absolved. Hence it follows that absolution by the priest is of no avail before one is first justified by grace and raised from the death of guilt, which means that the priest himself has no power over guilt. Here the $S H$ notes that some speak of the power of the keys insofar as it operates within the penitent's intention to confess, while others say it is operative in the act of confession itself. If the first, then the intention is already included in contrition, and in contrition guilt is blotted out. In that sense it is true that the power of the keys does extend in a certain manner to the blotting out of guilt. For someone cannot be justified and released from his guilt unless he intends to confess to a priest. Yet-and this is a crucial distinction-if we are speaking of the power as it operates within the act of absolving, then it cannot extend itself to guilt. This is because someone who worthily comes forward for absolution already approaches the priest contrite and spiritually resuscitated; his guilt has therefore already been forgiven him. ${ }^{94}$

We find a similar argument presented by the Dominican Albert the Great in his Sentences Commentary circa 1242 to 1245 . The keys, according to Albert, can open up the kingdom by removing the impediment of sin when the contrite person has the intention to confess and perform satisfaction. In fact, says Albert, nothing prevents the key from operating prior to the external action of the priest. For although the guilt and punishment are both absolved in contrition, this absolution does not

92 SH Bk IV, Q20, M6, Ar3, p. 610.

93 SH Bk IV, Q20, M7, Ar1, p. 611.

94 SH Bk IV, Q21, M1, p. 614. 
occur by the power of contrition alone, but rather also by the power of the keys. ${ }^{95}$ Only under these conditions, attached to the vow of the contrite penitent to confess, does Albert allow that the priest may be said to absolve from guilt and eternal penalty. Otherwise, though, we say that the priest only absolves by relaxing part of the penalty. This is because an offense against God is by definition infinite, and so its absolution cannot be subject to finite human power. ${ }^{96}$

As the $S H$ continues, it notes that there are others who say that the priest, through the power of the keys, functions as a mediator between God and human beings, such that through the priest, the sinner ascends to God. The priest at once speaks on behalf of humans, while through him God deigns to descend to humans. Having sought grace on behalf of the sinner, the absolution granted presupposes that divine grace has been bestowed upon the penitent, since the priest would never absolve anyone he does not believe God has already absolved. Thus in answer to the question whether the power of the keys extends as far as the blotting out of guilt, the $S H$ determines that it does insofar as the priest beseeches God to absolve the penitent, but never as though the priest himself actually confers such absolution. ${ }^{97}$ The priest therefore does not even function as an instrumental cause with respect to the forgiveness of sins. The penitent's guilt is erased directly by God in contrition, which is itself a condition resulting from divine grace. Note that Bonaventure said much the same thing in his own Sentences Commentary, observing that when one says that the power of the keys extends to the deletion of guilt, this refers to imploring and beseeching, which is signified in the blessing of the priest. The priest himself, says Bonaventure, does not actually impart absolution to the penitent, which means that the power of the keys does not, properly speaking, extend its reach to guilt. ${ }^{98}$ Compare the position of these Franciscans, as well as the Dominican Albert, to that of the Dominican Thomas Aquinas for whom the power of the keys is the instrumental efficient cause of the grace received in the sacrament, whereas contrition constitutes only a necessary disposition for the reception of that grace. ${ }^{99}$

95 Albert the Great, Commentarii in Sententiarum 4.18.1, in Opera Omnia, 38 vols, Étienne César Auguste Borgnet (Paris: Apud Ludovicum Vivès, 1890-9), 29:764.

96 Albert the Great, Commentarii in Sententiarum 4.18.7 (Borgnet, 29:775).

97 SH Bk IV, Q21, M1, p. 615.

98 Bonaventure, Commentaria in quatuor libros Sententiarum Magistri Petri Lombardi IV, d. 18, p. 1, a. 2, q. 1, in Doctoris Seraphici S. Bonaventurae opera omnia, 10 vols (Quaracchi: Collegium S. Bonaventurae, 1882-1902), 4:473. In 1946 Ralph Ohlmann was chagrinned to conclude that Bonaventure's conception of the power of the keys, which exercises no causality in the removal of sin but instead presupposes its removal, did not correspond to the position taken at the Council of Trent. See Ralph Ohlmann, 'St Bonaventure and the Power of the Keys: Part I,' Franciscan Studies 6 (1946): 293-315; Ralph Ohlmann, 'St Bonaventure and the Power of the Keys: Part II,' Franciscan Studies 6 (1946): 437-65.

99 Thomas Aquinas, Quaestiones disputatae de veritate, q. 28, a. 8, in Sancti Thomae de Aquino Opera omnia: iussu Leonis XIII P. M. edita, vol. 22/3 (Rome: Editiori di san Tommaso, 1967), 841-4. 
At all events, things get even more interesting when the question resurfaces as to whether God remits the debt of eternal punishment absolutely or only conditionally. Note that here in Question 21, which is devoted to the Power of the Keys, the SH seems to present a different take on the matter than we encountered in Question 18 on Confession. First, the context: the $S H$ has confirmed that the power of the priest's keys does not extend to eternal punishment, thereby in keeping with Peter Lombard's teaching. Yet it is objected that God can both per se and through his minister absolve the debt of damnation, and this should be understood as complete absolution. For example, if a sinner is contrite and wishes to confess but cannot find a priest, then God does absolve that person apart from his minister. But when there are priests available to whom one can confess and also receive a penance, then it will be through the sacerdotal ministry that the penitent is unqualifiedly and completely (simpliciter et complete) absolved of eternal punishment. Consequently, it asked whether God forgives sin unqualifiedly or conditionally (absolute vel cum conditione). It would seem the latter, because God absolves no one of eternal punishment unless under the condition that one be reconciled to the Church through the ministry of the Church. For no penitent is absolved of eternal punishment except under the condition that one make his confession to the minister, or at least resolves to do so given the opportunity. ${ }^{100}$

On the other hand, absolution from eternal punishment occurs through the conferral of grace which takes place unqualifiedly. For, properly speaking, God withdraws grace from nobody; it is the sinner himself who expels grace. The point here is that God does not confer grace on someone only to take it away later, which would be the case were he only to confer it conditionally. Moreover, by releasing someone from eternal punishment, God binds that person to purgatory. But if God releases the person conditionally, then the obligation remains so long as the condition exists, and while the condition exists he or she is not unqualifiedly absolved from eternal punishment. This would result in a situation whereby someone is bound to purgatory even as he is not absolved of eternal punishment. Yet that would mean that one is not yet bound to purgatory so long as the condition exists, since one cannot be simultaneously bound to purgatory and eternal punishment. Additionally, there would arise the incongruous situation in which someone would be at once worthy of eternal life even while bound to the debt of eternal punishment up until the time that one completes the satisfaction enjoined by the priest. ${ }^{101}$

As it is, however, the $S H$ cannot accept the notion that God may be said to absolve conditionally from guilt and eternal punishment, unless one were speaking very broadly (quodam modo extraneo). Better to state more plainly and accurately (proprius et verius) that God absolves unqualifiedly and absolutely from guilt and eternal punishment. For if God were only to absolve conditionally, a person could 
at once be a debtor to eternal punishment while presently in a state of grace. In other words, someone will have been freed from sin and thereby justified prior to his or her confession even as that person is walking around with eternal punishment hanging over his head until he finds a priest. And to those who say that God only absolves from eternal punishment under the condition that the penitent be reconciled to the Church and make one's confession to a minister, the $S H$ reiterates the foundational principle that the intention to be reconciled and to confess belongs by definition to contrition itself. This means that no one is sufficiently contrite apart from possessing the will and the intention to confess given the opportunity. The nature of contrition thus understood, it is therefore unqualifiedly and absolutely true (simpliciter vera et absolute) that God absolves the contrite person from guilt and eternal punishment with no implicit condition attached (nec est cointelligenda conditio ali$q u a) .{ }^{102}$ In this vein, William of Melitona had maintained that contrition would have no efficacy unless sacramental confession made to a priest were to follow, precisely because negligence or contempt for confession unqualifiedly (simpliciter) renders contrition inefficacious. ${ }^{103}$

Does the treatment of God's conditional absolution present an inconsistency between Question 18 and Question 21; and if so, what do we make of that? If, in fact, Question 18 proposes conditional absolution, then it seems to accord with Alexander's Gloss, which in turn concurs with the position of Richard of St Victor. If the Gloss is clearly the work of Alexander, does that mean that Question 18 is Alexander's own view and Question 21 a later, even non-Alexandrian, position taken by one of the Franciscans who completed the $S H$ ? That seems to make the most sense, because the post-Alexandrian editor of Question 21 regarded the notion of conditional divine absolution as untenable. Even as he let stand Alexander's own position in Question 18 , he would correct the situation in a section on the power of the keys to which Alexander himself had not contributed. Not wishing thoroughly to discredit the argument of his illustrious master, however, he allowed (as we saw above) that one could speak of conditional absolution, just so long as one was speaking broadly. Hence the editor is only rendering more precise his teacher's position and in that way tying up a few loose ends; continuity is thereby preserved.

The question remains as to which Franciscan might have made this alteration. I have not found in William of Melitona's Quaestiones de sacramentis nor in Bonaventure's Sentences Commentary any discussion of unqualified and conditional absolution. As for Odo Rigaldus, it seems that he never produced a commentary on the fourth book of the Sentences, and he does not address this topic in his De contritione. ${ }^{104}$ It should be said that certain similarities in Book 4 of the $\mathrm{SH}$ with William of Melitona's Quaestiones-a few of which we noted-have led some to doubt the

102 SH Bk IV, Q21, M2, Ar2, p. 617.

103 William of Melitona, Quaestiones de Sacramentis, tr. 6, p. 3, q. 13 (Piana and Gal, 2:1046).

104 Killian Lynch, 'The Alleged Fourth Book of Odo Rigaud and Related Documents,' Franciscan Studies 9 (1949): 87-145. 
Alexandrian provenance of the whole of $\mathrm{SH}$ Book 4. And it seems that Question 23 on Indulgences might be taken almost entirely from Bonaventure. That Book 4 was compiled from the works of William and Bonaventure is quite possible. Although Bonaventure himself not only claimed to have had the $S H$ open before him, but he never questioned its authenticity. ${ }^{105}$ We have certainly not resolved this larger matter here, but perhaps our discussion of conditional absolution will have shed some small ray of light on what still remains an opaque path.

105 See Victorin Doucet, 'The History of the Problem of the Authenticity of the Summa,' Franciscan Studies 7 (1947): 26-41. 